\title{
PENGARUH PEMBERIAN EKSTRAK DAUN KELOR (Moringa oleifera) DAN SAMBILOTO (Andrographis paniculata) TERHADAP INCOME OVER FEED COST AYAM BROILER
}

\author{
Puji Astuti ${ }^{*}{ }^{*}$, Heru Suripta ${ }^{1)}$ \\ ${ }^{1}$ Akademi Peternakan Karanganyar \\ ${ }^{*}$ Corresponding author: tutiamir88@gmail.com
}

To cite this article:

Astuti, P., \& Suripta, H. (2021). Pengaruh Pemberian Ekstrak Daun Kelor (Moringa oleifera) dan Sambiloto (Andrographis paniculata) terhadap Income Over Feed Cost Ayam Broiler. JIA (Jurnal IImiah Agribisnis) : Jurnal Agribisnis dan IImu Sosial Ekonomi Pertanian, 6(4), 141 - 146. doi:http://dx.doi.org/10.37149/jia.v6i4.19483

Received: July 08, 2021; Accepted: August 30, 2021; Published: August 31, 2021

\begin{abstract}
The purpose of this study is to determine the effect of giving kelor (Moringa oleifera) leaf, and Sambiloto (Andrographis paniculata) extracts on income over the feed cost of broiler chickens. The material used is $60 \mathrm{DOC}$ (day old chicken) strain ross on average initial weight $93.7 \mathrm{~g} / \mathrm{head}$. The study was designed using a completely randomized design (CRD) with four treatments and three replications, and each treatment using the five chickens. The treatment consisted of feeding $5 \mathrm{ml} /$ iter of Moringa leaf and Sambiloto extract, T0: control treatment, T1: bitter extract, T2: Moringa and bitter extract (1:1), T3: Moringa extract. The parameters observed were fed consumption, drinking water consumption, feed conversion ratio, feed cost per gain, and income per feed cost. Feed cost per gain and income per feed cost were analyzed descriptively. The result showed that drinking water consumption ((196,18-209,07 ml/head/day) was not significantly different. The lowest feed consumption $(85,32 \mathrm{~g} / \mathrm{head} /$ day) and feed conversion $(1,34)$ were found in the treatment of Moringa extracts. The lowest feed cost per gain $(\mathrm{Rp} / \mathrm{kg})$ was the treatment with Moringa leaf extract, the highest income over feed cost (Rp. 9.358,84/kg) was the administration of Moringa extract. It can be concluded that Moringa leaf extract gave the best results on feed consumption, feed conversion ratio, feed cost per gain, and income over feed cost
\end{abstract}

Keywords: bitter extracts; income over feed cost; moringa extracts

\section{PENDAHULUAN}

Ayam pedaging (broiler) merupakan salah satu produk unggas yang menghasilkan bahan pangan yang bergizi. yang tinggi. Ayam berumur 30 hari yang dipelihara dalam waktu yang relatif singkat memiliki berat lebih dari 1,6 kg/ekor. Pertumbuhan yang cepat dapat menurunkan kekebalan tubuh ayam broiler. Untuk meningkatkan pertumbuhan dan daya tahan ayam broiler maka perlu dilakukan penambahan bahan aditif pada pakan. Namun karena penggunaan feed additive meninggalkan residu sehingga dapat membahayakan konsumen. Di lain sisi bahwa masyarakat sangat memperhatikan kualitas produk karkas ayam broiler yang bebas dari residu dan layak untuk dikonsumsi, sehingga diperlukan penambahan feed additive dalam ransum. Zat aditif merupakan zat non-nutritif yang memiliki manfaat khusus dan dapat meningkatkan efektivitas dari pakan. Zat aditif tersebut harus dapat diserap dengan baik oleh ayam yang diternakkan (Ravindran, 2013)

Penggunaan imbuhan pakan dalam ransum ditujukan untuk meningkatkan konsumsi, kecernaan, ketahanan ayam broiler dan mengurangi tingkat stress. Biasanya bahan tambahan makanan yang digunakan adalah antibiotik sintetik karena praktis dan langsung memberikan hasil.. Pemberian feed additive seperti antibiotik sintetik akan menghasilkan residu dalam karkas ayam broiler. Apabila mengkonsumsi daging ayam yang mengandung residu dikhawatirkan menimbulkan resistensi terhadap antibiotik sintetik, sehingga diperlukan feed additive yang bukan antibiotik sintetik. Bahan imbuhan pakan alternatif pengganti antibiotik sintetik yang dapat diperoleh dari tanaman obat atau biofarmaka terbukti dapat meningkatkan asupan dan nafsu makan ayam broiler. Alternatif 
pengganti antibiotik sintetik adalah tanaman obat antara lain kelor (Moringa oleifera) dan sambiloto (Andrographis paniculata).

Tanaman kelor dimanfaatakan sebagai tanaman obat maupun makanan, mulai dari daun, kulit, batang, biji hingga akarnya (Purba, 2020). Tanaman kelor memiliki banyak kandungan senyawa aktif, terutama yang paling menonjol adalah antioksidan terdapat pada bagian daunnya (Tukiran et al., 2020). Daun kelor memiliki kandungan bahan aktif yaitu saponin, tanin, alkaloid, fenol dan flavonoid (Pandey et al., 2012). Saponin memiliki fungsi sebagai antimikroba yang mempercepat proses regenerasi dan revitalisasi sehingga mampu meningkatkan kekebalan tubuh, tidak mudah terserang penyakit, dan sistem pencernaan yang baik. Senyawa flavonoid berperan sebagai antioksidan dan dapat mendukung sistem kekebalan tubuh. Tanin memiiki sifat antiseptik dan antimikroba sehingga memberikan pengaruh yang baik dalam saluran pencernaan. Kandungan lain dalam Moringa adalah katekol, steroid, triterpen, antrakuinon, alkaloid, dan gula. (Saputri, 2019) menyatakan daun kelor kaya akan gizi dengan kandungan protein mencapai $27 \%$. Unsur asam amino yang terkandung dalam Moringa oleifera, seperti scordinine, methionine, lysine dan cystine, dapat merangsang pertumbuhan ayam, menambah bobot badan, dan meningkatkan energi (Kusmardika, 2019; Desy et al., 2021).

Sambiloto (Andrographis paniculata Ness) merupakan tanaman asli dari India. (Indrati et al., 2019) melaporkan bahwa flavonoid dan tanin pada sambiloto mempunyai potensi sebagai antelemintik. Sambiloto secara in vitro mempunyai daya hambat terhadap glukosidase kapang (Rais, 2013). Diterpenoid dan flavonoid merupakan kandungan kimia utama sambiloto ((Rochmat, 2015); (Rachmani, 2018). Komponen bioaktif utama tanaman ini adalah andrografolid, suatu diterpenoid yang memiliki rasa yang sangat pahit (Royani, 2014). Rasa pahit dari andrograpolid tersebut dapat merangsang nafsu makan karena dapat meningkatkan sekresi kelenjar ludah, meningkatkan produksi, dan antibodi serta memperkuat sistem kekebalan tubuh. Andrographolide dalam sambiloto mampu menghambat perlekatan (attachment) virus dengan reseptor pada sel (Setiyono, 2013)

Penelitian sebelumnya yang dilakukan oleh (Dewi et al., 2014) pemberian ekstrak daun kelor (Moringa oleifera) sebanyak $5 \%$ dalam air minum, dapat meningkatkan konsumsi pakan, air minum, bobot akhir, pertambahan bobot ayam broiler umur 2-6 minggu, dan menghasilkan konversi pakan yang efisien. Perhitungan pendapatan diperlukan untuk menentukan apakah usaha layak dikembangkan. Perhitungan pendapatan berdasarkan biaya pakan (Income over feed cost=IOFC) hanya mengukur pendapatan usaha ayam broiler dengan melihat biaya ransum yang dikeluarkan selama pemeliharaan (Rasyaf, 2011). Income Over Feed Cost (IOFC) adalah selisih dari pendapatan dengan biaya pakan dalam pemeliharaan ayam. Pendapatan berdasarkan biaya pakan merupakan perhitungan yang digunakan untuk melihat biaya pakan yang merupakan biaya terbesar $(70 \%)$ dalam usaha peternakan dan dampaknya terhadap (Setyaningrum et al., 2014). Penelitian ini dirancang untuk mengetahui pengaruh penggunaan ekstrak terhadap income over feed cost serta performans ayam broiler.

\section{MATERI DAN METODE}

Penelitian dilaksanakan pada bulan April 2020 di Unit Praktek Ternak Akademi Peternakan Karanganyar, Penelitian ini menggunakan ayam broiler sebanyak 60 ekor, ekstrak daun kelor dan sambiloto. Pakan yang digunakan memiliki kandungan air $13 \%$, protein $22 \%$, lemak $4 \%$, serat $5 \%$, kalsium $0,9 \%$, dan phosphor $0,6 \%$.

Penelitian menggunakan metode eksperimen. Perlakuan yang diterapkan adalah pemberian ekstrak air kelor dan sambiloto sebanyak $5 \mathrm{ml} /$ liter air minum yaitu T0 : Kontrol, tanpa pemberian ekstrak, T1 : Pemberian ekstrak daun sambiloto, T2 : Pemberian $50 \%$ ekstrak daun kelor dan $50 \%$ ekstrak sambiloto, dan T3 : Pemberian ekstrak daun kelor.

Variabel yang diamati yaitu konsumsi air minum (ml/ekor) yaitu banyaknya air yang dikonsumsi oleh ayam selama 24 jam. Data diperoleh dari jumlah air minum yang diberikan dikurangi sisa air minum, diberikan 2 kali sehari Konsumsi pakan (g/ekor) adalah banyaknya pakan yang dikonsumsi oleh ayam selama 24 jam. Data diperoleh dari jumlah pakan yang diberikan dikurangi sisa pakan, diberikan 2 kali sehari. Konversi pakan, diperoleh dari konsumsi pakan dibagi pertambahan bobot badan. Feed Cost Per Gain adalah besarnya biaya pakan yang diperlukan untuk menghasilkan $1 \mathrm{~kg}$ bobot badan. Income Over Feed Cost adalah hasil penjualan ayam dikurangi biaya pakan.

Pembuatan ekstrak kelor atau sambiloto : Kelor atau sambiloto dicampur air suhu $90^{\circ} \mathrm{C}$ dengan perbandingan 1:10 selama 20 menit. Campuran didinginkan kemudian disaring. Ekstrak yang didapatkan dipanaskan pada suhu $60^{\circ} \mathrm{C}$ sampai didapatkan ekstrak kental. 
Rancangan penelitian menggunakan Rancangan Acak Lengkap (RAL) pola searah. Analisis data yang diperoleh melalui analisis varians. Perbedaan antar perlakuan diuji dengan uji jarak berganda Duncan. Data feed cost per gain dan income over feed cost dianalisis secara deskriptif.

\section{HASIL DAN PEMBAHASAN}

Hasil pemberian ekstrak sambiloto dan kelor pada ayam broiler dapat dilihat pada Tabel 1 sebagai berikut:

Tabel 1. Konsumsi air minum, pakan dan konversi pakan ayam broiler yang mendapatkan eskstrak sambiloto dan kelor

\begin{tabular}{lcccc}
\hline & T0 & T1 & T2 & T3 \\
\hline Konsumsi air minum (ml/ekor/hari) & 209,07 & 196,18 & 196,49 & 197,04 \\
Konsumsi pakan (g/ekor/hari) & $95,23^{\mathrm{a}}$ & $91,4^{\mathrm{ab}}$ & $90,19^{\mathrm{ab}}$ & $85,32^{\mathrm{b}}$ \\
Konversi pakan & $1,53^{\mathrm{a}}$ & $1,49^{\mathrm{a}}$ & $1,46^{\mathrm{a}}$ & $1,34^{\mathrm{b}}$ \\
\hline Keterangan: superskrip yang berbeda pada baris yang sama & \multicolumn{4}{c}{ menunjukkan berbeda nyata $(\mathrm{P}<0,05)$}
\end{tabular}

\section{Konsumsi Air Minum}

Pemberian ekstrak kelor dan sambiloto dalam air minum berbeda tidak nyata $(P>0,05)$. Kelor mengandung tannin yang rasanya pahit (Putra et al., 2016). Tanin merupakan golongan polifenol yaitu senyawa aktif tumbuhan yang mempunyai rasa sepat (Rosyidah, 2016). Senyawa tanin merupakan senyawa astringent mempunyai beberapa khasiat antara lain menyebabkan rasa sepat (pahit) karena saat dikonsumsi terbentuk ikatan silang antara tanin dengan protein atau glikoprotein di rongga mulut. Rasa (taste) pada ayam memiliki peranan yang relatif kecil untuk menentukan banyaknya konsumsi pakan atau minum. Ayam kurang peka terhadap rasa karena jumlah alat perasa ayam 24 buah lebih kecil dibanding alat perasa anak sapi yaitu 25000 buah. Seperti halnya penelitian (Kadja et al., 2018) yang menyatakan kandungan zat bioaktif (flavonoid, saponin, tanin, kurkumin dan minyak atsiri) yang terdapat dalam obat herbal pada perlakuan tidak mempengaruhi konsumsi air minum ternak ayam. Sesuai dengan pendapat (Seto, 2018), ayam mengkonsumsi air minum antara 1,6-2 kali dari pakan. Standar konsumsi air minum rata-rata ayam broiler adalah $180 \mathrm{ml} /$ ekor/hari. Sedangkan dalam penelitian ini konsumsi air minum rata-rata adalah 199,70ml/ekor/hari, konsumsi air minum dalam penelitian ini lebih tinggi dari standar dikarenakan suhu rata - rata lingkungan yang mencapai $30^{\circ} \mathrm{C}$. Dalam penelitian ini konsumsi air minum pada perlakuan control : 2,2 x konsumsi pakan, ekstrak sambiloto : 2,15 x konsumsi pakan, Ekstrak sambiloto-kelor : 2,18 x konsumsi pakan, Ekstrak kelor : 2,31 x konsumsi pakan

\section{Konsumsi Pakan}

Konsumsi pakan ayam broiler masing-masing perlakuan sebesar kontrol $=95,23$; ekstrak sambiloto $=91,4$; ekstrak sambiloto-kelor $=90,19$; ekstrak kelor $=85,32 \mathrm{~g} /$ ekor $/$ hari. Hasilnya menunjukkan bahwa pakan berbeda nyata $(P<0,05)$. Perlakuan tanpa pemberian ekstrak berbeda nyata dengan ekstrak kelor, sedangkan perlakuan kontrol tidak berbeda dengan ekstrak sambiloto dan kombinasi sambiloto-kelor, perlakuan ekstrak kelor tidak berbeda nyata dengan kombinasi sambiloto dan kombinasi sambiloto-kelor.

Ekstrak daun kelor mampu memberikan hasil konsumsi pakan yang lebih sedikit karena aktivitas zat antioksidan daun kelor lebih tinggi dibandingkan antioksidan vitamin $\mathrm{E}$ pada kisaran $\mathrm{pH}$ $4-9$ dan suhu $5-25^{\circ} \mathrm{C}$ (Wangcharoen \& S. Gomolmanee, 2013). Zat antioksidan daun kelor dapat meningkatkan kinerja organ dalam, khususnya pancreas sehingga ayam dapat terlindungi. Antioksidan dapat mencegah ayam mengalami stress oksidatif sehingga memacu pertumbuhan melalui peningkatan metabolisme tubuh maupun penyerapan nutrisi dalam tubuh ayam.

Berbeda dengan hasil penelitian (Dewi et al., 2014), bahwa pemberian ekstrak daun kelor (Moringa oleifera) sebanyak 5\% pada ayam broiler umur 2 - 6 minggu dapat meningkatkan konsumsi ransum, air minum, berat badan akhir, pertambahan berat badan, dan FCR yang efisien. Penelitian pemberian tepung kelor $24 \%$ dalam ransum menunjukkan adanya penurunan tingkat konsumsi pakan (Ayssiwede et al., 2011). Penurunan konsumsi pakan karena daun kelor memiliki kandungan energi yang tinggi dan juga mempunyai kemampuan untuk meningkatkan protein yang dibutuhkan dalam pencernaan ungags, sehingga hanya dengan konsumsi pakan yang lebih rendah sudah mencukupi kebutuhan energi tubuh ayam broiler.

Berdasarkan standar Japfa Comfeed Indonesia rata-rata konsumsi pakan 104,8 gram/ekor/hari (selama 5 minggu), sedangkan hasil penelitian menunjukkan rata-rata konsumsi 
pakan ayam broiler sebesar 90,53 gram/ekor/hari, maka dapat dikatakan bahwa konsumsi pakan ayam broiler lebih rendah.

\section{Konversi Pakan}

Hasil analisis ragam menunjukkan pemberian ekstrak kelor dan sambiloto mempengaruhi konversi pakan $(\mathrm{P}<0,05)$. Perlakuan kontrol $(1,53)$ tidak berbeda nyata dengan perlakuan ekstrak sambiloto dan kombinasi sambiloto-kelor $(1,49$ dan 1,46$)$, sedangkan pemberian ekstrak kelor $(1,34)$ berbeda nyata dengan kontrol, ekstrak sambiloto dan kombinasi sambiloto-kelor. Konversi pakan pada perlakuan ekstrak kelor lebih kecil dibandingkan perlakuan yang lainnya karena pada kelor mengandung antioksidan yang lebih tinggi dan lebih baik sehingga konsumsi pakan lebih sedikit dan berpengaruh terhadap perhitungan konversi pakan. Selain itu antioksidan berfungsi sebagai anti stress dan meningkatkan kinerja organ dalam tubuh ayam sehingga mampu meningkatkan metabolism tubuh dan penyerapan nutrisi. Daun kelor mengandung bahan aktif seperti flavonoid, saponin, tannin, dan senyawa fenolik lainnya yang berfungsi sebagai antimikroba (Pandey et al., 2012). Bahan aktif antimikroba dapat menghancurkan membran sel bakteri dan memecah bakteri dengan meningkatkan permeabilitas dinding sel. Dengan adanya antimikroba, nutrisi dalam ransum dapat diserap optimal oleh saluran pencernaan, sehingga meningkatkan efisiensi penggunaan ransum.

Zat aktif utama dalam sambiloto adalah Andrographolide yang mempunyai multi efek farmakologis (Cahyawati, 2021).Tanaman sambiloto mengandung saponin, flavonoid, dan tanin yang memiliki rasa pahit. Rasa pahit sambiloto dapat meningkatkan sekresi kelenjar ludah sehingga merangsang nafsu makan, antibodi, dan mendukung kekebalan tubuh. Ekstrak sambiloto memberikan hasil yang kurang efisien dibandingkan dengan kelor.

Hasil penelitian (Alifian et al., 2018) menyatakan konversi pakan ayam broiler fase finisher yang diberi herbal kunyit dan temulawak adalah 1,74. Konversi pakan penelitian ini lebih rendah dari penelitian Alifian et al., (2018). Hal ini dimungkinkan karena pemberian herbal (kelor dan sambiloto) sebagai feed additive pada ternak ayam broiler dapat meningkatkan efisiensi pakan dan kesehatan ternak.

\section{Biaya Pakan per Kg Bobot Badan (Feed Cost Per Gain)}

Pakan memegang peranan penting dalam proses produksi ayam broiler. Hal ini dikarenakan dalam produksi ayam broiler, biaya pakan merupakan biaya terbesar tertinggi (70-80\%). Biaya pakan untuk pertambahan bobot badan (feed cost per gain) adalah biaya per kilogram bobot badan ayam. Menurut (Saffar \& Khajal, 2010), biaya pakan dipengaruhi oleh harga pakan dan konsumi pakan. Semakin rendah konsumsi pakan, maka semakin rendah biaya pakan, berarti semakin ekonomis. Analisis feed cost per gain untuk mengetahui perlakuan yang paling ekonomis dalam menghasilkan daging.

Tabel 2. Feed cost per gain ayam broiler yag mendapatkan ekstrak kelor dan sambiloto

\begin{tabular}{|c|c|c|c|c|}
\hline Uraian & T0 & T1 & T2 & T3 \\
\hline Biaya pakan (Rp) & 18.798 & 18.042 & 17.804 & 16.844 \\
\hline Pertambahan bobot badan $(\mathrm{kg})$ & 1,74 & 1,71 & 1,73 & 1,79 \\
\hline Feed cost per gain $(\mathrm{Rp} / \mathrm{kg})$ & 10.803 & 10.550 & 10.291 & 9.410 \\
\hline
\end{tabular}

Pada Tabel 2 dapat dilihat konversi pakan pada penelitian lebih rendah (1,71-1,79) dibandingkan dengan konversi pakan hasil penelitian (Sariati et al., 2020) yaitu 1,82, sehingga menghasilkan feed cost per gain yang baik pula. Perlakuan ekstrak kelor memiliki rata - rata feed cost per gain Rp 9,41 yang berarti diperlukan Rp 9,41 untuk menaikkan 1 gram bobot badan. Perlakuan ini memiliki rata - rata feed cost per gain lebih baik dibandingkan perlakuan lainnya karena faktor konversi pakan yang efisien yaitu biaya pakan rendah dalam membentuk bobot badan. Konsumsi pakan rendah dipengaruhi oleh zat antioksidan yang terkandung dalam kelor berpengaruh terhadap kinerja organ dalam ayam broiler dan meningkatkan penyerapan nutrisi pakan sehingga dihasilkan bobot badan yang baik pula.

\section{Pendapatan atas Biaya Pakan (Income Over Feed Cost)}

Income Over Feed Cost adalah selisih penerimaan dengan biaya pakan. IOFC adalah ukuran besarnya pendapatan atas biaya pakan. Menurut (Ardiansyah et al., 2013) konsumsi pakan, bobot akhir, harga pakan dan harga ayam mempengaruhi pendapatan atas biaya pakan.

Hasil analisis IOFC pada Tabel 3. memperlihatkan perlakuan T3 (ekstrak kelor) merupakan perlakuan dengan IOFC terbesar. Nilai IOFC terendah terdapat pada perlakuan tanpa pemberian 
ekstrak. Nilai IOFC dipengaruhi oleh harga ekstrak, harga pakan, pertambahan bobot badan dan harga per kg bobot ayam.

Tabel 3. Income over feed cost ayam broiler yang mendapatkan ekstrak kelor dan sambiloto

\begin{tabular}{lcccc} 
& T0 & T1 & T2 & T3 \\
\hline Penerimaan $(\mathrm{Rp} / \mathrm{kg})$ & 26.629 & 26.204 & 26.421 & 27.285 \\
Biaya pakan $(\mathrm{Rp} / \mathrm{kg})$ & 18.798 & 18.042 & 17.804 & 16.844 \\
Income over feed cost $(\mathrm{Rp} / \mathrm{kg})$ & 7.831 & 8.162 & 8.617 & 10.441 \\
\hline
\end{tabular}

PerlakuanT3 (ekstrak kelor) memiliki pendapatan atas biaya pakan (IOFC) paling tinggi (Rp 10.441), artinya perlakuan T3 (ekstrak kelor) memiliki selisih pendapatan terhadap biaya pakan sebesar Rp 10.441. Selisih yang besar diantara perlakuan yang lainnya dipengaruhi penerimaan yang lebih tinggi dikurangi dengan biaya pakan yang lebih rendah. Total biaya pakan dipengaruhi oleh harga ekstrak dan biaya pakan. Konsumsi pakan yang sedikit dan FCR yang efisien menghasilkan bobot badan yang tinggi sehingga mendapatkan keuntungan yang besar dibandingkan perlakuan yang lainnya. IOFC penelitian ini lebih tinggi dibanding IOFC hasil penelitian (Syadik, 2017) yang menggunakan tepung buah nipah dalam pakan ayam.

Menurut (Rasyaf, 2011) menyatakan bahwa semakin baik pemeliharaan yang dilakukan maka akan semakin tinggi nilai IOFC. IOFC tinggi berarti penerimaan yang didapat tinggi dengan biaya pakan rendah, sehingga dapat diartikan pemeliharaan ayam lebih efisien. Faktor-faktor yang memengaruhi nilai IOFC adalah jumlah pakan, harga pakan, bobot ayam, dan harga jual ayam. (Setyaningrum et al., 2014) menyatakan nilai IOFC tinggi atau rendah karena perbedaan besar atau kecil antara biaya penjualan dan biaya pakan.

\section{KESIMPULAN}

Penambahan ekstrak kelor (Moringa oleifera) dapat menurunkan konversi pakan sehingga pakan lebih efisien dibandingkan pemberian ekstrak sambiloto (Andrographis paniculata) maupun kombinasi ekstrak sambiloto-kelor. Pemberian ekstrak daun kelor dapat menurunkan feed cost per gain (biaya pakan per kg bobot badan) dan meningkatkan Income Over Feed Cost (pendapatan atas biaya pakan).

\section{REFERENSI}

Alifian, M. D., Nacrowi, \& D. Evvyernie. (2018). Pengaruh Pemberian Imbuhan Pakan Herbal terhadap Performa Ayam Broiler. Buletin Makanan Ternak, 16(1).

Ardiansyah, F., T. Syahrio, \& N. Khaira. (2013). Perbandingan performa dua strain ayam jantan tipe medium yang diberi ransum komersial broiler. . IImiah Peternakan Terpadu .

Ayssiwede, S. B., A.Dieng, H. Bello, \& C.A.AM. (2011). Effects Of Moringa Oleifera Leaves Meal Incorporation in Diets on Growth Performances, Carcass Characteristics and Economics Results of Growing Indigenous Senegal Chickens. Pakistan Journal of Nutrition.

Cahyawati, P. N. (2021). A Mini Review: Efek Farmakologi Andrographis Paniculata (Sambiloto). . WICAKSANA, Jurnal Lingkungan \& Pembangunan .

Desy, Kalsum, U., \& O.R. Puspitarini. (2021). Potensi Tepung Daun Kelor (Moringa oleifera) Sebagai Feed Additive Broiler (Literatur Review. Jurnal Dinamika Rekasatwa, 4(1).

Dewi, T. K., IG.N.G. Bidura, \& D.P.M.A, Candrawati. (2014). Pengaruh Pemberian Ekstrak Daun Kelor (Moringa oleifera) dan Bawang Putih (Allium sativum) Melalui Air Minum Terhadap Penampilan Broiler Umur 2 - 6 Minggu. Journal PeternakanTropika, 2(3).

Indrati, R., Sawitri, M., \& Wisaptiningsih, U. (2019). Prosiding Seminar Nasional Teknologi Peternakan dan Veteriner. Prosiding Seminar Nasional Teknologi Peternakan Dan Veteriner, 447-455.

Kadja, E. F., J.F. Bale Therik, \& M.U.E. Sanam. (2018). Pengaruh Pemberian Dekok Daun Sirsak, Kunyit Putih, Dan Daun Kersen Serta Kombinasinya Dalam Air Minum Terhadap Performans Dan Kolesterol Darah Ayam Petelur Jantan Yang Diinfeksi Bakteri Eschericia Coli. Jurnal Kajian Veteriner, 6(1).

Kusmardika, D. A. (2019). Potensi Aktivitas Antioksidan Daun Kelor (Moringa Oleifera) Dalam Mencegahan Kanker. Journal of Health Science and Physiotherapy, 1(1).

Pandey, A., Pandey RD, Tripathi P, Gupta PP, \& Haider J, B. S. (2012). Moringa oleifera Lam. (Sahijan) - a plant with a plethora of diverse therapeutic benefits: an update retrospection. . Medicinal and Aromatic Plants, 1(1), 2-8. 
Purba, E. C. (2020). Kelor (Moringa oleifera Lam.): Pemanfaatan Dan Bioaktivitas. Jurnal Pro-Life, $7(1)$.

Rachmani, E. P. N. , S. P. dan A. E. N. (2018). Aktivitas Antioksidan Fraksi Flavonoid Bebas Andrographolid Dari Herba Sambiloto (Andrographis paniculata). Pharmacy Medical Journal, 1(2).

Rais, I. R. , A. G. S. S. W. dan A. E. Nugroho. (2013). Penentuan Aktivitas Isolat Andrografplid Terhadap a Amilase dan a glucosidase Menggunakan Metode Apostolidis dan Mayur. Trad. Med. J, 18(3).

Rasyaf, M. (2011). Panduan Beternak Ayam Pedaging. Kanisius.

Ravindran, V. (2013). ). Poultry feed availability and nutrition in developing countries.

Rochmat, A. (2015). Karakterisasi Senyawa Flavonoid Ekstrak Sambiloto (Andrographis paniculata) Yang Mempunyai Aktivitas Inhibisi Terhadap Enzim Siklooksigenase-2 Secara In Vitro. Jurnal Integrasi Proses, 5(2).

Royani, J. I. D. H. dan S. W. (2014). Analisa Kandungan Andrographolide Pada Tanaman Sambiloto (Andrographis paniculata) IDari 12 Lokasi Di Pulau Jawa. Jurnal Bioteknologi Dan Biosains Indonesia., 1.

Saffar, A., \& Khajal, F. (2010). Application of Meal Feeding and Skip-A-Day Feeding With or Without Probiotics for Broiler Chickens Grown at High-Altitude to Prevent Ascites Mortality. American Journal of Animal and Veterinary Sciences.

Saputri, G. R. , T. A. I. P. (2019). Penetapan Kadar Protein Pada Daun Kelor Muda Dan Daun Kelor Tua (Moringa oleifera L.) Dengan Menggunakan Metode KJELDAH. Jurnal Analis Farmasi, $4(2)$.

Sariati, Nuraini, \& Muh. Amrullah Pagala. (2020). Pengaruh Pemberian Temulawak (Curcuma xanthoriza,roxb) dalam Pakan terhadap Penampilan Produksi Ayam Broiler. . . Jurnal IImiah Peternakan Halu Oleo. .

Setiyono, A. dan N. B. (2013). Potensi Tanaman Obat untuk Penanggulangan Flu Burung: Uji In Vitro pada Sel Ver. Jurnal Sain Veteriner, 31(1).

Seto, R. (2018). Manajemen Stok Air Peternakan Broiler. Infovet Mei (2018).

Setyaningrum, F., M. Handayani, \& A. Setiadi. (2014). Income Over Feed Cost Pemeliharaan Ayam Broiler Betina Dengan Ransum Mengandung Tepung S. molesta . Animal Agriculture Journal, 3(2), 172-178.

Syadik, F. (2017). Produktivitas Ternak Ayam Kampung Super Terhadap Ransum Tepung Buah Nipah (Nypah fruticans Wurmb) Dengan Level yang Berbeda. Jurnal AgroPet, 14(1).

Tukiran, Mauren Gita Miranti, Idah Dianawati, \& Fauzia Indah Sabila. (2020). Aktivitas Antioksidan Ekstrak Daun Kelor (Moringa oleifera Lam.) Dan Buah Bit (Beta vulgaris L.) Sebagai Bahan Tambahan Minuman Suplemen. Jurnal Kimia Riset, 5(2).

Wangcharoen, W., \& S. Gomolmanee. (2013). Antioxidant Activity ChangesDuring Hot-Air Drying of Moringa oleifera Leaves. Maejo Int. J. Sci.Technol, 7(3). 